\title{
Understanding the Research Process and Historical Trends in English for Medical Purposes Using Scientometrics and Co-Occurrence Analysis
}

\author{
Nematullah Shomoossi ${ }^{1}$, Mostafa Rad ${ }^{2}$, Mansoureh Fiezabadi ${ }^{3}$, Esmaeil Vaziri $^{4}$, Mostafa Amiri $^{5}$ \\ ${ }^{1}$ Department of English, School of Medicine, Sabzevar University of Medical Sciences, Sabzevar, Iran \\ ${ }^{2}$ Department of Nursing, School of Nursing, Sabzevar University of Medical Sciences, Sabzevar, Iran \\ ${ }^{3}$ Department of Information Science and Knowledge Studies, School of Medicine, \\ Sabzevar University of Medical Sciences, Sabzevar, Iran \\ ${ }^{4}$ Department of Information Science and Knowledge Studies, Faculty of Humanities, \\ University of Zabol, Zabol, Iran \\ ${ }^{5}$ Department of Basic Sciences, School of Medicine, Gonabad University of Medical Sciences, Gonabad, Iran
}

\section{SUMMARY}

The present study used scientometrics and word co-occurrence analysis to identify the most important topics and to assess trends in English for medical purposes over time. Documents indexed in Scopus and Web of Science were used to examine various indicators such as keywords, countries, organizations, and authors. Search results were preprocessed through BibExcel to create a file for mapping, and word co-occurrence analysis was applied to evaluate the publications. Also, scientific maps, author's network, and country contributions were depicted using VOSviewer and NetDraw. The most productive authors and countries were determined. Regarding the trend analysis, highly frequent words were examined at six-year intervals. The findings indicated that 81 countries, 1,304 authors, and 799 organizations have contributed to the scientific mobility of this field. Keyword co-occurrence analysis indicated that topics have shifted from language-specific foci to interactive domains. These findings offer evidence-based information about the past and present trends in EMP research topics and trends, as well as its future directions, moving from linear patterns (solely related to linguistic components) towards a more interrelated pattern of issues clustering around a medical education and learning topics.

Key words: English for medical purposes (EMP), English for specific purposes (ESP), medical English, scientometrics, word co-occurrence analysis 


\section{INTRODUCTION}

Throughout the 2500-year history of medicine, different countries and languages have had instrumental impacts on its development, including Greek, Latin, Roman, and Arabic, as well as English during the past centuries (1-3). More recently, globalization and internationalization of higher education have benefitted from the effect of English as the scientific lingua franca in medical education (4), particularly after signing the Bologna Declaration in 1999, although other issues such as patient contact, communication among colleagues within individual countries, and teaching activities are still conducted in the local mother tongues (5).

Nevertheless, research on the role and significance of a language in medical education and healthcare sciences has been on the rise since the second half of the $20^{\text {th }}$ century. Almost all conferences and a growing number of scholarly journals in medicine use English as their official language (6). Such trends in medical communication and healthcare professions have indeed motivated the teaching of English in medical and paramedical settings (7). On the whole, an almost independent field (i.e. English for Medical Purposes) within ESP (i.e. English for Specific Purposes) has developed in response to this urgent demand to learn English specifically for medical purposes. The field is also known as Medical English, EMAP (English for Medical Academic Purposes) (8), and Medical ESP, among others.

EMP, the term we will use throughout this paper as the umbrella term for all alternative terms, is characterized with outstanding ESP features (4); moreover, it involves adults at a tertiary level or professional settings with basic, intermediate language proficiency; learners are already motivated; they need language for both academic achievement as well as social survival in the field; the field deals with future workplace needs and requires unique methodologies and activities; it relies on a specific register revolving around medical terms, and entails language-specific and discourse-specific training (4). Historically, the first time EMP was recorded in (the abstract, title or keywords of) an article was in 1983 (9). The field came into vogue further with attempts to internationalize medical education, diverting attention to intercultural interactions in academic settings as well as between colleagues, patients and doctors, nurse-doctor communications, etc. (10).

The interrelationship between EMP and medical education has been investigated in research; in the present study, trends and directions governing the English for Medical Purposes will be closely investigated. One of the reliable ways to track science development is the study of scientific literature (i.e. journal articles, news, reviews, comments, letters, editorials, newspaper articles, etc.), co-authorship, patents, citations, and co-citations (11). Among the many ways of measuring research activities, scientometrics has earned a significant place in evaluating scientific output by counting the number of papers and their impact on scientific flourishing, the number of citations, patents, etc. Also, co-occurrence analysis aids in evaluating the publications by bibliometric indicators (12). In addition, mapping the search results to prepare authors' network, identifying the most productive authors and their relationships, together with density drawings help us assess the current status and future trends in a given field.

Therefore, the present study was designed to investigate the most important topics and trends in EMP research output, and to portray scientific maps using scientometrics and co-occurrence analysis to identify the most important topics and assess their trends over time. Co-occurrence analysis is a method of identifying the most important research topics or concepts in a given field as it presupposes co-occurring words in a document as an indicator of their relationship; also, investigating keywords in the publications of a given field can reveal the likely directions in research (13). Due to the interdisciplinary nature of the study, the study was confined to research articles merely on EMP. In a word, scientific mapping will help us identify interrelationships between a topic and its subtopics (12).

\section{MATERIALS AND METHODS}

The present descriptive study was based on bibliometric and scientometrics techniques, with the intention of investigating the current status of scientific productions in EMP indexed in SCOPUS and Web of Science (WOS) by the end of 2017. In the present study, quantitative methods were applied using scientometrics techniques. All EMP research productions (indexed by March 7, 2018) in Web of Science and Scopus were inestigated to include documents related to Medical English and English for Medical Purposes.

\section{Strategies of search}

The following search strategies were adopted to retrieve all documents related to EMP, covering various fields such as keywords, titles and abstracts. WOS search strategy was as follows: 
- TS = ("English for medical purposes" OR "English for specific purposes" OR "medical English" OR "English for doctors" OR "English for nurses" OR "English for health" OR "English for medical students")

-Timespan: 1983-2017. Indexes: SCI-EXPANDED, SSCI, ESCI.

And Scopus search strategy was as follows:

-TITLE-ABS-KEY ("English for medical purposes" OR "English for specific purposes" OR "medical English" OR "English for doctors" OR "English for nurses" OR "English for health" OR "English for medical students") AND (EXCLUDE (PUBYEAR, 2018))

\section{Procedures}

The statistical sample came out to be 358 articles from WOS, and 744 documents from Scopus; the retrieved documents in these two databases overlapped. However, for minimizing the redundancy, the BibExcel software was used to identify redundant items, to preprocess and clean the data, and to prepare network output. Finally, a total of 856 unique documents appeared from the two databases. Furthermore, information such as frequency of articles, number of authors per article, citations, relevant journals, countries and institutions collaborating in publication were extracted to investigate the current status of scientific productions in EMP.

\section{Word co-occurrence analysis}

Co-occurrence analysis was used to identify the most important research topics or concepts. Accordingly, two concepts or terms occurring together in one single document indicate their relationship. Therefore, an investigation of co-occurring concepts or keywords in documents can reveal the research trends and topics in a discipline (14). Upon extraction of keywords, a unified list of them was prepared by the researchers, and one keyword was selected for each concept. This was done for avoiding redundancy and drawing more accurate maps. In this stage, keywords with no semantic load and stop-words were omitted. The list was used for both portraying the scientific maps and determining the topics and trends in EMP literature.

\section{Scientific mapping}

VOSviewer 1.6.7 was used for scientific mapping and clustering the themes in order to determine the hot topics and trends (11). Research performance maps contribute to the understanding of the general image of the research in a field, and to the analysis of trends and changes in different time intervals; they are considered as tools in identifying areas of research on a certain topic and their interrelationships (5).

VOSviewer maps are characterized with a spectrum of colors differentiating the importance and density of the topics and concepts. Red spots show the highest density and frequency of articles, and yellow highlights the second place in density. Therefore, density maps show important topics and fields in respective research areas. Based on interval-based categories, VOSviewer renders labelled network and density maps. VOSviewer maps shows the relationships between themes by their distance, and draws no line between them, and the size of a circle shows the frequency of articles about that concept. Thus, topics and keywords with highest co-occurring frequency are seen closer and more proximal to one another.

\section{Density drawings}

Density Drawings were prepared to visualize the trend of this particular field of research (i.e. EMP). For drawing density maps and keyword analysis, the major keywords with highest frequency were examined by 6year intervals: before 2000, 2000-2005, 2006-2011, and 2012-2017. In order to visualize all keywords, a general map of all keywords with at least 4 interrelationships was prepared in VOSviewer.

Also, to prepare EMP authors' network, the search results were entered into VOSviewer software, and the 60 most productive authors and their relationships were identified. In addition, countries contributing to the production of articles were retrieved, and those ranking among the first 10 were determined.

NetDraw 2.153 (4) and UNICET 6.581 (5) were used to delineate indicators of international scientific collaboration. Countries with significant research output in EMP were initially organized by frequency, and sorted by country names, to make the drawing of maps more convenient. In the maps produced, nodes represent countries, and lines indicate quality of scientific collaboration. Circle sizes show the number of articles produced by that country, and density of the lines represent times of collaborations between the nodes. Descriptive statistics were calculated in Excel.

\section{RESULTS}

In the present study, a total of 856 documents were investigated, with the oldest dating back to 1895 , 
which was cited as a Correspondence in British Medical Journal titled as "Medical English as She is Wrote", Br Med J 1895; 2 (https://doi.org/10.1136/bmj.2.1824.1529), published on December 14th, 1895. From 2013 to 2017, 477 articles (55.77\%) were published. Totally, 856 documents were extracted through search strategies; out of these, 627 documents were research articles (73.25\%). Second to the articles, publication of conference papers $(12.27 \%)$ seems to be of almost the same weight as all other published stuff, excluding articles; news items and editorials were the least frequent $(0.12 \%)$ (Table 1$)$.

Table 1. Frequency of document types

\begin{tabular}{lcc}
\hline \multicolumn{1}{c}{ Document types } & Frequency & Percentage \\
\hline Articles & 627 & 73.25 \\
Conference papers & 105 & 12.27 \\
Reviews & 34 & 3.97 \\
Book chapters & 28 & 3.27 \\
Editorial materials & 16 & 1.87 \\
Books & 14 & 1.64 \\
Book reviews & 7 & 0.82 \\
Articles in press & 5 & 0.58 \\
Erratum & 4 & 0.47 \\
Notes & 4 & 0.47 \\
Conference reviews & 3 & 0.35 \\
Short surveys & 3 & 0.35 \\
Letters & 2 & 0.23 \\
Meeting abstracts & 2 & 0.23 \\
Editorials & 1 & 0.12 \\
News items & 1 & 0.12 \\
\hline \multicolumn{1}{c}{ Total } & $\mathbf{8 5 6}$ & $\mathbf{1 0 0}$ \\
\hline \hline
\end{tabular}

As for the countries, the highest number of articles $(n=94)$ came from USA, followed by China $(n=65)$ and Spain $(n=65)$. Iran appeared to rank the eighth $(n=$ 33). Citations were higher for articles from USA (1,048 citations) and UK (331 citations) (Graph 1). All in all, 81 countries contributed to the production of 856 research documents in EMP. However, ten major countries contributing to the EMP research output may be listed as USA, China, Spain, Taiwan, Japan, UK, France, Iran, Russia, and Czech Republic.

The cooperation between researchers from different countries was investigated, too. The highest frequency of joint research was observed between USA and Spain (4 articles), Greece and England, Australia and England, Canada and USA, Finland and Germany, England and USA, Australia and China, each with two joint research articles; other countries shown in Graph 1 had two joint research studies. Bigger circles represent higher research output, and the thickness of the lines indicates higher degrees of cooperation in EMP research.

Among the organizations, the highest contributions were reported by Islamic Azad University (Iran), University of Michigan (USA), and University of Hradec Kralove (Czech Republic); other institutions are listed in Table 2. All in all, 799 organizations or institutes contributed to the production of 856 articles on EMP.

As for the most prolific authors in EMP field, Simonova I. (12 articles), Salagermeyer F. ( 9 articles), and Paltridge B. (8 articles) ranked first to third in publishing research articles. However, the most considerable cooperation between authors was observed between Simonva and Poulova (5 articles), Pacak and Pratt (3 articles); the rest of authors (Graph 2) had at least two cases of joint research publications. Graph 2 represents the number of 
articles in circles, and cases of cooperation by the thickness of the lines. The most conspicuous cases of cooperation are shown in six-article, four-article, and three- article clusters. In a nutshell, 1,304 authors contributed to the production of 856 articles in EMP.

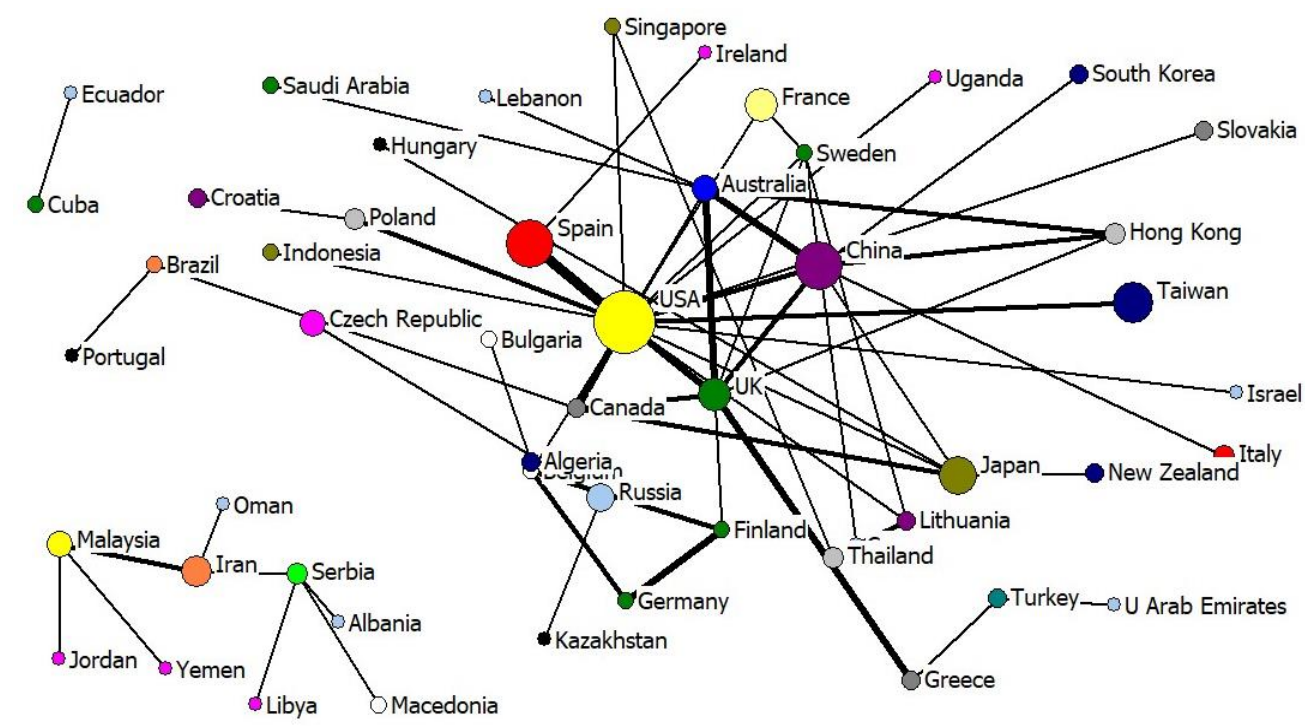

Graph 1. Production and cooperation of countries in joint research in EMP

Table 2. Contribution of organizations or institutes to the production of articles on EMP

\begin{tabular}{lccc}
\hline \hline Organization & Country & $\mathrm{N}$ & $\%$ \\
\hline Islamic Azad University & Iran & 15 & 1.75 \\
University of Michigan & USA & 13 & 1.52 \\
University of Hradec Kralove & Czech Republic & 13 & 1.52 \\
City University of Hong Kong & Hong Kong & 11 & 1.29 \\
University of Nis & Serbia & 10 & 1.17 \\
National Kaohsiung University of Applied Sciences & Taiwan & 10 & 1.17 \\
The Hong Kong Polytechnic University & Hong Kong & 9 & 1.05 \\
University of Electro-Communications & Japan & 9 & 1.05 \\
National Cheng Kung University & Taiwan & 9 & 1.05 \\
University Kebangsaan & Malaysia & 9 & 1.05 \\
\hline \hline
\end{tabular}




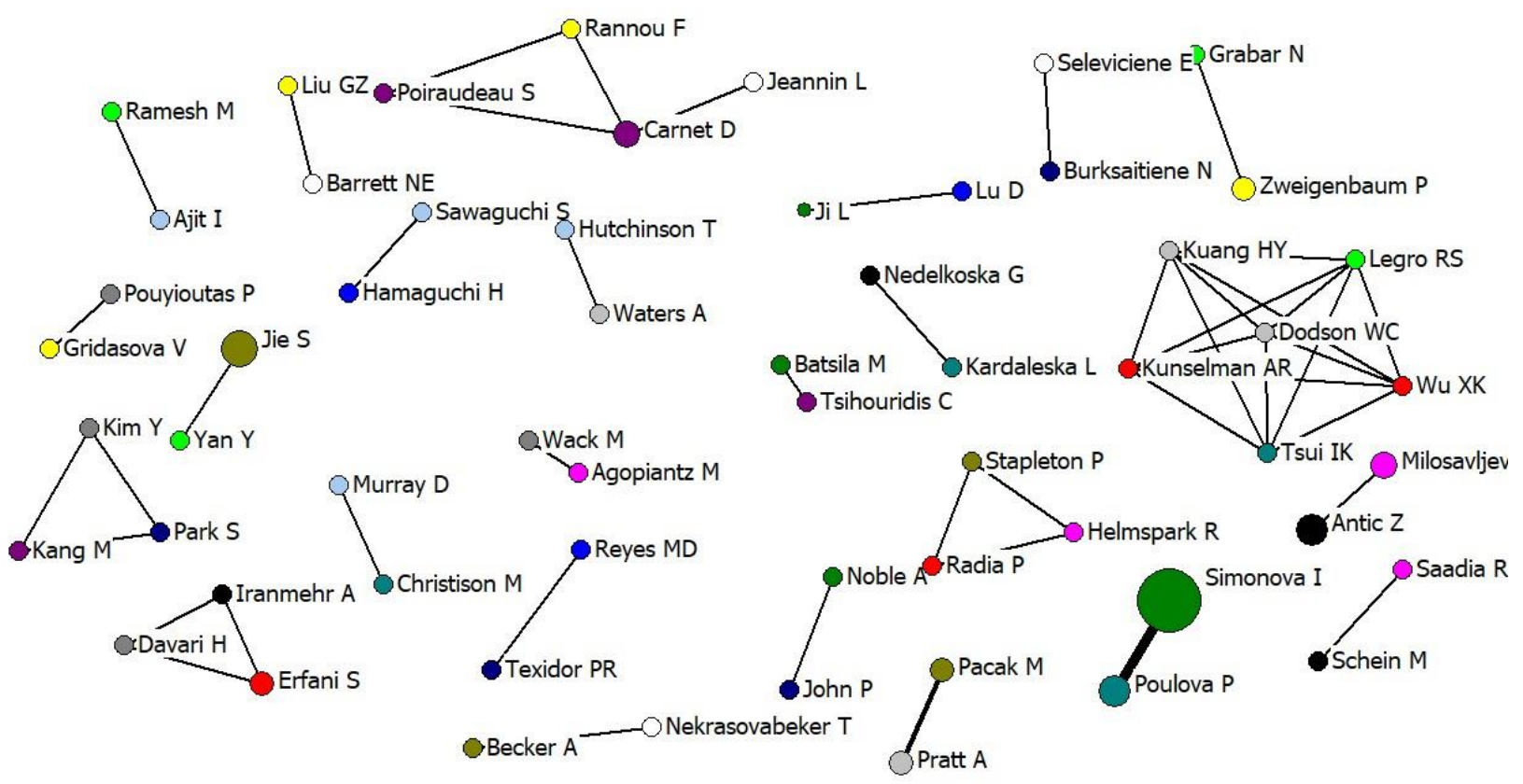

Graph 2. Authors with at least two joint articles in EMP research production

\section{Publication trends and research topics}

The cooccurrence of keywords assigned by the authors of the articles were the basis of determining publication trends and research topics, since authors are deemed as specialists in their own fields and contribute to the development of their discipline. To achieve this, labelled and density maps were drawn using VOSviewer, to determine the clusters of keywords' networks. Based on interval-based techniques, VOSviewer renders labelled networks and density maps. VOSviewer maps show the relationships between themes by their distance, and draws no lines between them; the size of a circle shows the quantity of articles about that concept. Therefore, topics and words with the highest frequency are seen closer to one another.

In data analysis, 4,539 keywords emerged from 856 documents, with an average of five keywords per document. Upon keywords unification, analysis was done in BibExcel, the output of which was then fed into VOSviewer. In order to observe the research topics and trends in the EMP field during the time intervals (i.e. before 2000, 2000-2005, 2006-2011, and 2012-2017), 20 top keywords were extracted based on their frequency (Table 3). Based on the resutls, the frequency of the keyword English for Specific Purposes was 0.02\% during the time interval before 2000, while it rose to $6.41 \%$ by the recent interval (2012-2017), showing the highest increase. However, the frequency of the keyword Terminology was $0.51 \%$ before 2000 , whereas it dropped to $0.07 \%$ in the most recent interval (2012-2017), showing the highest decrease.

In addition to cooccurrence maps and trends of topics in time intervals, a general map of keywords with at least 4 cooccurrence instances were portrayed to visualize a general view of the publication in EMP studies (Figure 1). As shown below, the hottest topics are education, language learning, teaching, learning systems and, to some extent, computational linguistics and educational technology; the second hot point appears to revolve around ESP, and context genre. Other topics on the cold side and less attended topics are visible in Figure 1.

For investigating the trends over time intervals, density maps were prepared based on the frequency of keywords in 6-year time intervals (i.e. before 2000, 20002005, 2006-2011, and 2012-2017) (Graph 2). The spectrum of colors shows the importance and density of the words and concepts. Red areas show the highest density and frequency of articles and yellow highlights the second place in density. Density visualization shows important topics and areas in the map (Figure 2). 
Table 3. Frequency and percentage of the 20 most frequent EMP keywords by time intervals

\begin{tabular}{|c|c|c|c|c|c|c|c|c|c|c|c|}
\hline \multirow[t]{2}{*}{ Rank } & \multirow{2}{*}{ Keyword } & \multicolumn{2}{|c|}{ Total } & \multicolumn{2}{|c|}{$<2000$} & \multicolumn{2}{|c|}{$\begin{array}{l}2000- \\
2005\end{array}$} & \multicolumn{2}{|c|}{ 2006-2011 } & \multicolumn{2}{|c|}{ 2012-2017 } \\
\hline & & $\mathbf{N}$ & $\%$ & $\mathbf{N}$ & $\%$ & $\mathbf{N}$ & $\%$ & $\mathbf{N}$ & $\%$ & $\mathbf{N}$ & $\%$ \\
\hline 1 & $\begin{array}{l}\text { English for Specific } \\
\text { Purposes (ESP) }\end{array}$ & 362 & 0.98 & 1 & 0.02 & 8 & 0.18 & 62 & 1.37 & 291 & 6.41 \\
\hline 2 & Teaching & 85 & 1.87 & 5 & 0.11 & 1 & 0.02 & 23 & 0.51 & 56 & 1.23 \\
\hline 3 & Students & 56 & 1.23 & 0 & 0.00 & 4 & 0.09 & 14 & 0.31 & 38 & 0.84 \\
\hline 4 & Education & 54 & 1.19 & 2 & 0.04 & 2 & 0.04 & 10 & 0.22 & 40 & 0.88 \\
\hline 5 & Curriculum & 40 & 0.88 & 5 & 0.11 & 5 & 0.11 & 15 & 0.33 & 15 & 0.33 \\
\hline 6 & Medical English & 37 & 0.82 & 1 & 0.02 & 2 & 0.04 & 10 & 0.22 & 24 & 0.53 \\
\hline 7 & Needs analysis & 36 & 0.79 & 0 & 0.00 & 0 & 0.00 & 6 & 0.13 & 30 & 0.66 \\
\hline 8 & E-learning & 34 & 0.75 & 0 & 0.00 & 0 & 0.00 & 8 & 0.18 & 26 & 0.57 \\
\hline 9 & Language & 33 & 0.73 & 12 & 0.26 & 3 & 0.07 & 9 & 0.20 & 9 & 0.20 \\
\hline 10 & Genre analysis & 23 & 0.51 & 1 & 0.02 & 2 & 0.04 & 5 & 0.11 & 15 & 0.33 \\
\hline 11 & Higher education & 23 & 0.51 & 0 & 0.00 & 0 & 0.00 & 7 & 0.15 & 16 & 0.35 \\
\hline 12 & Terminology & 23 & 0.51 & 8 & 0.18 & 4 & 0.09 & 8 & 0.18 & 3 & 0.07 \\
\hline 13 & Motivation & 21 & 0.46 & 0 & 0.00 & 0 & 0.00 & 4 & 0.09 & 17 & 0.37 \\
\hline 14 & $\begin{array}{l}\text { English for Academic } \\
\text { Purposes (EAP) }\end{array}$ & 20 & 0.44 & 0 & 0.00 & 1 & 0.02 & 6 & 0.13 & 13 & 0.29 \\
\hline 15 & Linguistics & 19 & 0.42 & 3 & 0.07 & 4 & 0.09 & 8 & 0.18 & 4 & 0.09 \\
\hline 16 & Medical education & 19 & 0.42 & 4 & 0.09 & 4 & 0.09 & 3 & 0.07 & 8 & 0.18 \\
\hline 17 & $\begin{array}{l}\text { Computational } \\
\text { linguistics }\end{array}$ & 17 & 0.37 & 0 & 0.00 & 0 & 0.00 & 3 & 0.07 & 14 & 0.31 \\
\hline 18 & Blended learning & 16 & 0.35 & 0 & 0.00 & 0 & 0.00 & 4 & 0.09 & 12 & 0.26 \\
\hline 19 & Writing & 15 & 0.33 & 3 & 0.07 & 4 & 0.09 & 2 & 0.04 & 6 & 0.13 \\
\hline 20 & Corpus linguistics & 15 & 0.33 & 0 & 0.00 & 1 & 0.02 & 4 & 0.09 & 10 & 0.22 \\
\hline & Total Articles & \multicolumn{2}{|c|}{94} & \multicolumn{2}{|c|}{45} & \multicolumn{2}{|c|}{45} & \multicolumn{2}{|c|}{211} & \multicolumn{2}{|c|}{647} \\
\hline
\end{tabular}

\section{Publication trends before 2000}

During the interval before 2000, the hottest points of research appeared to be language, curriculum, medical education, telemedicine, professions such as nurse and foreign worker, hospitals, as well as computer analysis and computer and instruction, to some extent. The pattern seemed to be linear; these words had the highest frequency and fell onto the hot region.

\section{Publication trends from 2000 to 2005}

During this time period, the pattern appeared to be linear, and topics with the highest frequency in the hot region were technology, technical writing, formal languages, simulations, writing, and posters.

\section{Publication trends from 2006 to 2011}

From 2006 to 2011, ESP, teaching, e-learning, students, computers, information systems, lifelong learning, as well as medical school and university curricula were on the focus, with the highest frequency. Other topics did not appear in the hot region, and the pattern seemed to shape in a roughly non-linear fashion.

\section{Publication trends from 2012 to 2017}

During this period, ESP, MOOCs, higher education, e-learning, curriculum, discourse analysis, interpersonal communication, culture and peer review were of the highest frequency. Other topics fell on the cold region, and the pattern again seemed to continue in nonlinear fashion. 


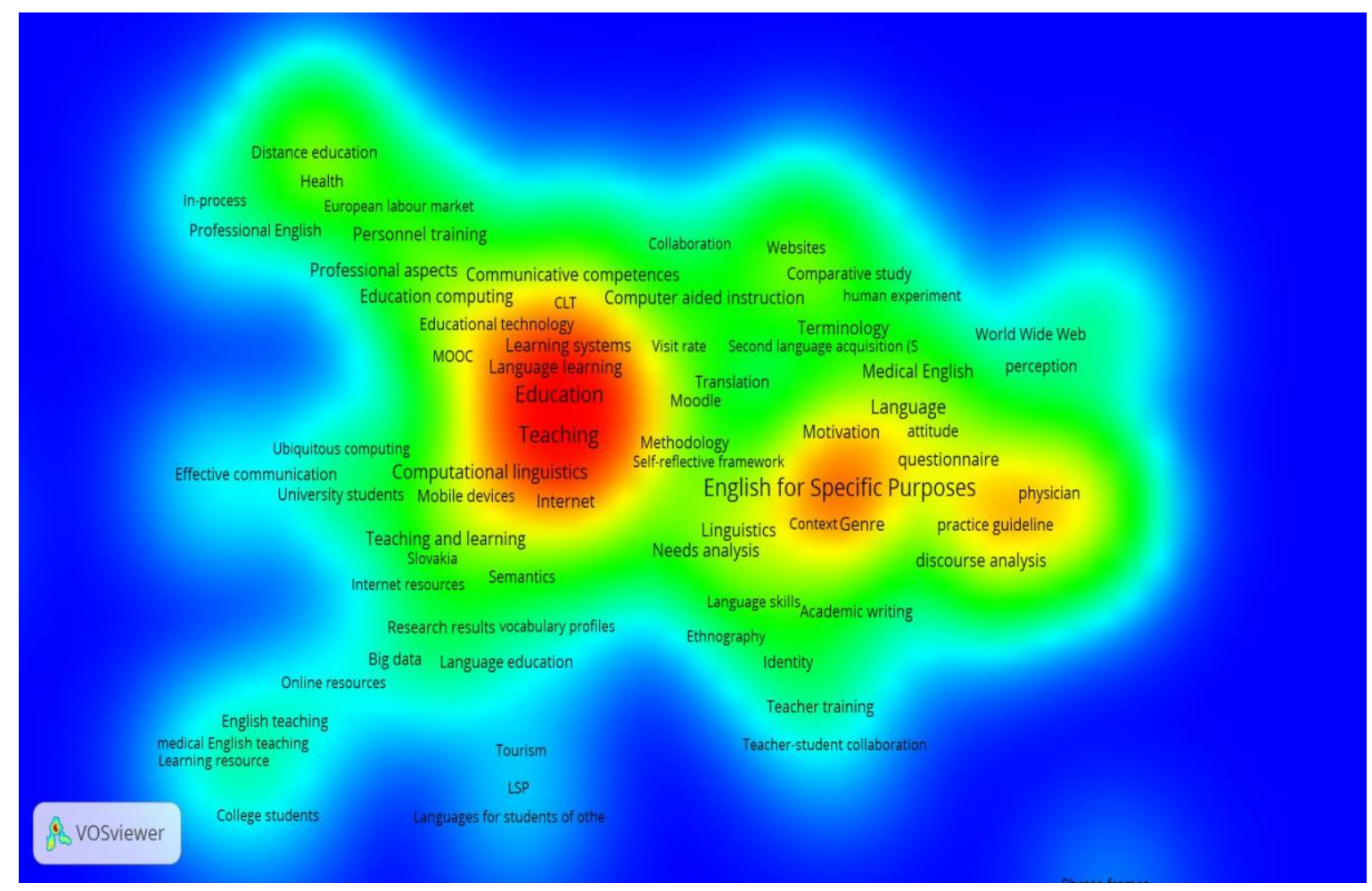

Figure 1. The co-occurrence map of all keywords with at least four co-occurrence cases

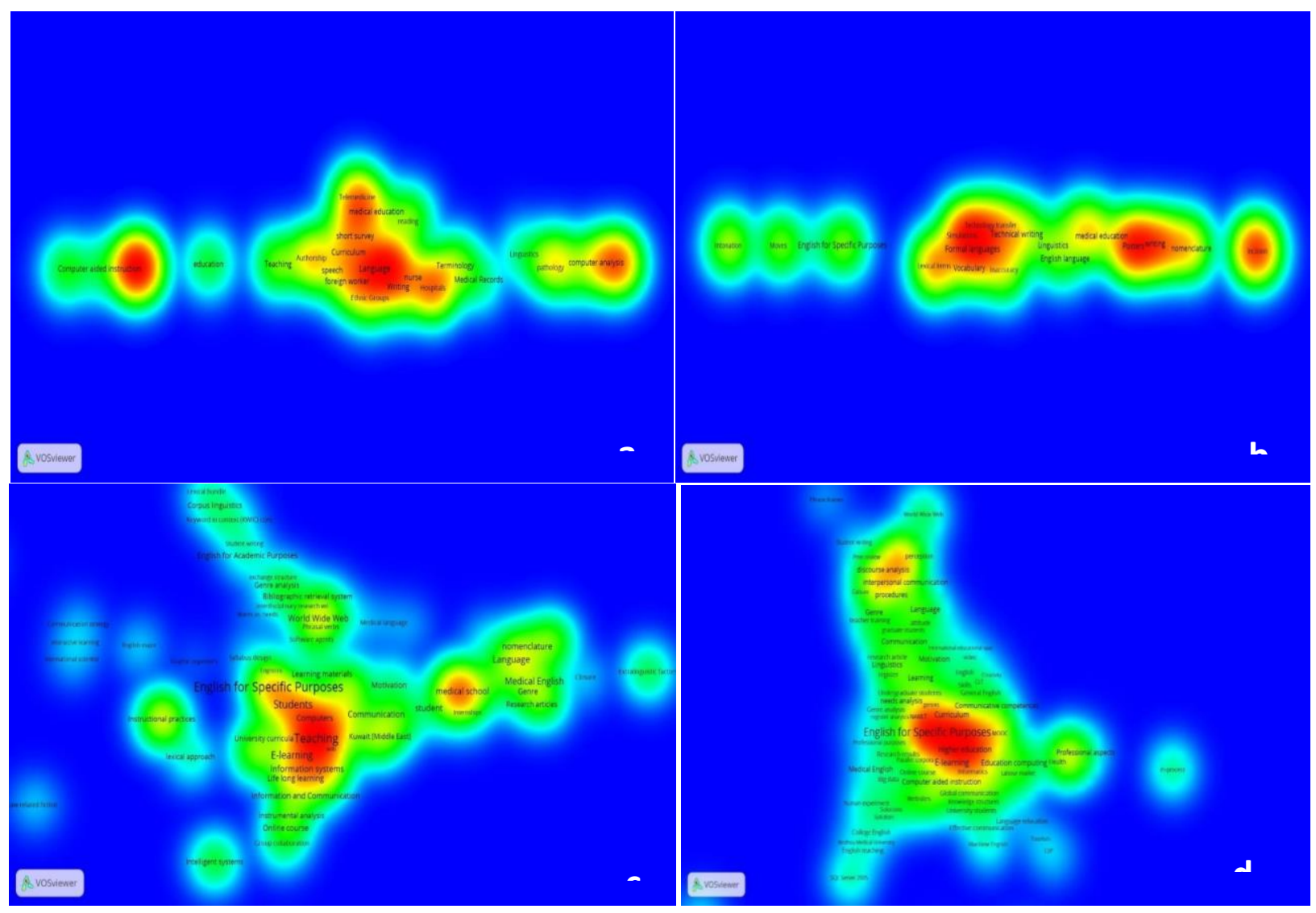

Figure 2. Density maps of EMP articles keywords in 6-year time intervals, $a=$ before $2000 / b=2000-2005 / c=2006-2011 / d=2012-2017$ 


\section{DISCUSSION}

In the present study, topics and trends of research production in EMP, as listed in Scopus and Web of Science (from its beginning to the end of 2017), were assessed, using co-occurrence analysis. Also, scientific maps indicative of dynamic expansion over time were drawn. Overall, 856 documents appeared in the search procedure, around $85 \%$ pertaining to the academic production in journals and conference papers. The total number of keywords in the documents were 4,539, out of which the first 20 most frequent keywords are listed in Table 3, with variable frequencies across time periods. Further, drawing co-occurrence maps in various time intervals rendered hot and cold zones of the area. The results will be discussed below under thematic headings.

\section{Personal and international contributions}

With regard to authorship, 1,304 authors contributed to the production of 856 EMP articles, the most prolific authors being Simonova I. (12 articles), Salagermeyer F. (9 articles), and Paltridge B. (8 articles). In contrast, the most considerable cooperation between authors was observed between Simonva and Poulova (5 articles), and Pacak and Pratt (3 articles). In fact, the number of authors started to inflate due to specialization of research expertise and collaborative efforts (15) as well as gift authorships in cases not covered here. However, for the enrichment of the focus of the study and developing international collaboration, publishing with one single author is declining in the present era, to the extent that international cooperation is becoming more common in academic publications (16).

In addition, 81 countries contributed to the production of 856 articles on EMP; ten outstanding countries may be listed as USA, China, Spain, Taiwan, Japan, UK, France, Iran, Russia, and Czech Republic. The highest international cooperation was observed be-tween USA and Spain (4 articles); other countries with two and three joint contributions were also noted. This trend has recently been appreciated as an international reputation for countries and institutes $(17,18)$.

As for the contribution of institutes, 799 institutes contributed to the production of 856 articles on EMP, the highest by Islamic Azad University (Iran), University of Michigan (USA), and University of Hradec Kralove (Czech Republic). In fact, institutes are now involved in both providing services and supporting research studies for the purpose of keeping up with global trends (19).

\section{Research orientations}

Originally, EMP appeared as a subfield in English for Specific Purposes (ESP), and their co-occurrence in studies is already predictable. In fact, the keyword ESP emerged during two of the four time intervals (20062011 and 2012-2017). English for Medical Purposes (EMP) appeared as early as 1983 in a review article on ESP (9), but the frequency of English for Specific Purposes (0.02\% before 2000) drastically rose to 6.41\% from 2012 to 2017, showing the highest co-occurrence with EMP in recent times. Trends other than ESP, as portrayed in Figure 1 and 2, indeed showed ups and downs in research orientations during the investigated time intervals, different aspects of which will be discussed below.

\section{The focus on the learners' needs}

During the latest intervals (i.e. 2006-2011 and 2012-2017), learner-centered approaches became the vogue, and issues such as course design, students, lifelong learning, university curricula, e-learning, and culture started to join the center of attention, with learners' needs and their responsibility in perspective. As Antić (14) suggests, language for specific purposes (LSP) teachers assist learners in becoming more flexible and more aware of their own learning styles and approaches, rather than being fed with preplanned packages. Indeed, issues realted to human participants (i.e. learners and teachers) started to grow and appear more frequently in studies. In contrast, components merely related to language (e.g. grammar, vocabulary, etc.) started to distance from research studies over time. For instance, the frequency of the keyword Terminology (0.51\% before 2000) dropped to $0.07 \%$ (from 2012 to 2017), showing the highest degree of fading.

\section{The role of technology}

Computers have been used in language learning and teaching since 1960s (20). Not surprisingly, during the four time intervals, computerized technology had a place in studies; besides, issues related to language learning and teaching, signs of technology applications showed remarkable co-occurrence during all time intervals, which include telemedicine, computers and instruction, and computer analysis (before 2000), technology and simulations (from 2000 to 2005), e-learning, computers, and information systems (from 2006 to 2011), MOOCs, and e-learning (from 2011 to 2017). Indeed, the 
contribution of information and communication technology (ICT) to ELT has always been in perspective (21), and recent developments have further added to its enrichment $(22,23)$.

\section{Academic English}

During the last three decades, research production has uncovered a significant boom due to widespread use of internet and the appearance of English as an International Language (EIL); conforming to the native speaker norms in phonology and grammar became necessary, while extra linguistic elements were adapted to the EIL contexts (24). Accordingly, rigorous procedures were suggested to check the accuracy of manuscripts. The role of language and its power to reflect science in the written format (25) were in perspective, too. In medicine, this growth was significantly admitted and almost all scholarly journals and conferences stressed on the accuracy of submitted manuscripts by careful scrutiny (26). Therefore, from 2000 onwards, expressions such as technical writing, formal languages, writing, posters (interval 2000-2005), interpersonal communication and peer review (interval 2011-2017) emerged in our search results.

\section{EMP and medical education}

Based on the results and evidence in both tables and figures, signs of close relationship between medical education as a scientific discipline and English language teaching which led to the development of a specialized branch within ESP (i.e. EMP) are observable. Professional purposes and places, where users apply English for medical purposes, are stressed. Workplaces such as hospitals and medical schools, professions such as nurses and doctors, specialized university curricula, needs, interpersonal communications as well as culture all appear around the periphery of the hot regions of the maps of the present study (Figure 1 and 2).

\section{CONCLUSION}

To conclude, these findings delineated the topics and trends of EMP research production. The scientific maps were indicative of dynamic expansion of the EMP research over time intervals, moving from linear patterns (solely related to linguistic components) towards a more interrelated pattern of issues clustering around a medical education and learning topics; moreover, hot and cold zones of the field were shown in maps. Accordingly, researchers and policy makers may likely forecast its dynamic directions for future research and take actions to either support them or to divert the routes as deemed reasonable. Possibly, these insightful ideas can shed light on the road to create a logical path with international contributions, leading to the development of both Medical Education, in general, and EMP, in particular.

\section{Acknowledgments}

We would like to gratefully thank the Research Committee of Sabzevar University of Medical Sciences, Sabzevar, Iran, for approving the study; we appreciate their support (Ethics Code: Ir.medsab.rec.2018.164, and the project code: 96223 , dated: 7 March, 2018). 


\section{References}

1. Bynum WF. Companion Encyclopedia of the History of Medicine (2 vol). Routledge, London, 2013: 20. https://doi.org/10.1016/S0270-6644(13)70021-3

2. Porter R. The Greatest Benefit to Mankind: A Medical History of Humanity (The Norton History of Science). WW Norton \& Company, New York, 1999.

3. Jackson M. The History of Medicine: A Beginner's Guide. Oneworld Publications, London, 2014.

4. Mićić S. Languages of medicine-present and future. JAHR 2013; 4: 217-33.

5. Baethge C. The languages of medicine. Deutsches Arzteblatt Int 2008; 105: 37-40.

https://doi.org/10.3238/arztebl.2008.0037

6. Pavel E. Teaching English for medical purposes. Bull Transilvania Univ Braşov, Series VII: Soci Sci Law 2014; 7:39-46.

7. Shomoossi N, Rad M, Rakhshani MH. Efficacy of English language programs as judged by nurses and students of nursing: Do nurses in Iran need to know English?. Acta Fac Med Naiss 2013; 30: 137-43 https://doi.org/10.2478/afmnai-2013-0005

8. Sinadinović D, Mićić S. Teaching English for medical academic purposes at the faculty of medicine in Belgrade, Serbia. Med Writ 2013; 22: 115-18. https://doi.org/10.1179/2047480613z.000000000119

9. Chaudron C. Languages for specific purposes. J Prag 1983; 7: 713-26.

https://doi.org/10.1016/0378-2166(83)90092-9

10. Shamsi Gooshki E, Pourabbasi A, Akbari H, Rezaei N, Kheradmand AA, Kheiry Z, Peykari N, Momeni Javid F, Hajipour F, Larijani B. Internationalization of medical education in Iran: A way towards implementation of the plans of development and innovation in medical education. J Adv Med Edu Prof 2018; 6: 43-48.

11. Bornmann L, Leydesdorff L. Scientometrics in a changing research landscape: Bibliometrics has be- come an integral part of research quality evaluation and has been changing the practice of research. EMBO Rep. 2014; 15: 1228-32.

https://doi.org/10.15252/embr.201439608

12. Sedighi M. Using co-word analysis method in mapping of the structure of scientific fields (A case study: The field of informetrics). Iran J Info Process Manage 2015; 30: 373-96.

https://jipm.irandoc.ac.ir/article-1-2583-en.html\&sw =Co-Occurrence

13. Van den Besselaar P, Heimeriks G. Mapping research topics using word-reference co-occurrences: A method and an exploratory case study. Scientometrics 2006; 68: 377-93.

https://doi.org/10.1007/s11192-006-0118-9

14. Antic Z. Forward in teaching English for medical purposes. Med Biol 2007; 14: 141-7.

15. Wren JD, Kozak KZ, Johnson KR, et al. The write position: A survey of perceived contributions to papers based on byline position and number of authors. EMBO Rep. 2007; 8: 988-91.

https://doi.org/10.1038/sj.embor.7401095

16. O'Brien TL. Change in academic co-authorship, 1953-2003. Sci, Tech, Hum Val 2012; 37: 210-34.

17. Jeong S, Choi JY, Kim J. The determinants of research collaboration modes: Exploring the effects of research and researcher characteristics on co-authorship. Scientometrics 2011; 89: 967-83. https://doi.org/10.1007/s11192-011-0474

18. Erfanmanesh MA, Rohani Vala A, Abrizah A. Coauthorship network of scientometrics research collaboration. Malaysian J Libr Info Sci 2012; 17: 73-79.

19. Cummings JN, Kiesler S. Collaborative research across disciplinary and organizational boundaries. Soci Stud Sci 2005; 35: 703-22. https://doi.org/10.1177/0306312705055535

20. Warschauer M, Healey D. Computers and language learning: An overview. Lang Teach 1998; 31: 57-71. 
21. Yang Y. Computer-assisted foreign language teaching: Theory and practice. J Learn Teach Res 2010; 1: 909-12.

https://doi.org/10.4304/jiltr.1.6.909-912

22. Viswanathan R. Teaching and learning through MOOC. Front Lang Teach 2012; 3: 32-40.

23. Watson J. The online facilitator: Exploring the nature of the role in MOOCs and other online courses. Paper presented at the conference e-learning symposium 2014.

https://www.llas.ac.uk/events/archive/6848
24. Ketabi S, Shomoossi N. Native speaker norms and teaching English as an international language. IJLS 2007; 1: 171-80.

25. Heddle NM, Ness PM. Reviewing manuscripts: Tips and responsibilities. Transfu 2009; 49: 2265-8.

https://doi.org/10.1111/j.1537-2995.2009.02390.x

26. Rennie D. Freedom and responsibility in medical publication: setting the balance right. JAMA 1998; 280: 300-2.

https://doi.org/10.1001/jama.280.3.300 


\title{
Razumevanje procesa istraživanja $i$ istorijskih trendova na engleskom jeziku za potrebe medicine korišćenjem scientometrije i analize kopojava
}

\author{
Nematullah Shomoossi ${ }^{1}$, Mostafa Rad ${ }^{2}$, Mansoureh Fiezabadi ${ }^{3}$, Esmaeil Vaziri ${ }^{4}$, Mostafa Amiri ${ }^{5}$ \\ ${ }^{1}$ Departman za engleski jezik, Medicinski fakultet, Univerzitet medicinskih nauka u Sabzevaru, Sabzevar, Iran \\ ${ }^{2}$ Departman za sestrinstvo, Fakultet za sestrinstoo, Univerzitet medicinskih nauka u Sabzevaru, Sabzevar, Iran \\ ${ }^{3}$ Departman za studije o informacijama i znanju, Medicinski fakultet, Univerzitet medicinskih nauka u Sabzevaru, \\ Sabzevar, Iran \\ ${ }^{4}$ Departman za studije o informacijama i znanju Fakultet za humanističke nauke, Univerzitet $u$ Zabolu, Zabol, Iran \\ ${ }^{5}$ Departman za bazične nauke, Medicinski fakultet, Univerzitet medicinskih nauka u Gonabadu, Gonabad, Iran
}

\section{SAŽETAK}

Ova studija je koristila scijentometrijsku analizu i analizu istovremenog pojavljivanja reči kako bi se identifikovale najvažnije teme i procenili trendovi engleskog jezika za potrebe medicine tokom vremena. Za ispitivanje različitih pokazatelja kao što su ključne reči, zemlje, organizacije i autori korišćeni su radovi indeksirani u bazama Scopus i Web of Science. Rezultati pretraživanja prethodno su obrađeni pomoću programa BibExel da bi se napravila datoteka za mapiranje, dok je analiza istovremenog pojavljivanja reči primenjena za procenu publikacija. Takođe, prikazane su naučne mape, mreža autora, kao i doprinos određenih zemalja koristeći programe VOSviewer i NetDraw. Određeni su najproduktivniji autori i najproduktivnije zemlje. Što se tiče analize trendova, najčešće korišćene reči ispitivane su u intervalima od šest godina. Rezultati su pokazali da je 81 zemlja, 1.304 autora i 799 organizacija doprinelo naučnoj mobilnosti ove oblasti. Analiza istovremenog pojavljivanja ključnih reči pokazala je da su se teme preusmerile sa jezički specifičnih domena na interaktivne domene. Ovi rezultati pružaju informacije zasnovane na dokazima o prošlim i sadašnjim trendovima u istraživačkim temama $i$ trendovima engleskog jezika za potrebe medicine, kao i njegovim budućim pravcima, polazeći od linearnih obrazaca (isključivo povezanih sa jezičkim komponentama) ka više međusobno povezanih obrazaca koji se grupišu oko medicinskog obrazovanja i tema za učenje.

Ključne reči: engleski za medicinske svrhe (EMP-eng.), engleski za posebne svrhe (ESP-eng.), medicinski engleski, scijentometrija, analiza zajedničke pojave reči 